\title{
ANALISIS PENGENDALIAN PERSEDIAAN BAHAN BAKU DENGAN METODE ECONOMIC ORDER QUANTITY (EOQ) PADA LAYLA BAKERY JEMBER
}

Ayu Dewi Larasati ${ }^{*}$, Naning Retnowati ${ }^{*}$, Alwan Abdurahman ${ }^{3 *}$ Financya Mayasari $^{4}$

Department of Agribusiness Management, Politeknik Negeri Jember 68101

Ayudlarasati@gmail.com ${ }^{1^{*}}$, naning_retnowati@polije.ac.id ${ }^{2 *}$, alwan abdurahman@polije.ac.id ${ }^{3^{*}}$

\begin{abstract}
Layla Bakery is an agroindustry business situated in Ambulu street Number 110, Balung Sub-district, Jember Regency. This business produces consist of banana bread, donuts, plain bread, comb bread and others. This research was aims to determine the optimal amount of flour raw material inventory that Layla Bakery should do, when is the right time to reorder flour raw materials and what is the optimal total cost of ordering for the procurement of flour raw materials. The analytical tool used in this research is EOQ (Economic Order Quantity) which includes the calculation of Quantity to determine the optimal number of raw material orders, ROP (Reorder Point) analysis tool to find out when is the right time to order raw materials back, safety analysis tools. Stock to determine safety stock and TIC (Total Inventory Cost) to calculate raw material total order cost. Based on the results of the analysis using the EOQ method, the amount of optimum raw materials was $3.179 \mathrm{~kg}$ with 18 times as the purchasing frequency in a year with reorder when the stock reach $704 \mathrm{~kg}$ with a total inventory cost of Rp. 351.827.600.
\end{abstract}

Keywords: Supply, Raw Material, Economic Order Quantity (EOQ)

\begin{abstract}
Abstrak
Layla Bakery merupakan usaha agroindustri yang terletak di Jalan Ambulu No.110, Kecamatan Balung, Kabupaten Jember. Produk dari Layla Bakery Jember antara lain roti pisang, donat, roti tawar, roti sisir dan lain-lain. Penelitian ini bertujuan untuk menentukan jumlah persediaan bahan baku tepung optimal yang seharusnya dilakukan Layla Bakery, kapan waktu yang tepat untuk melakukan pemesanan kembali bahan baku tepung dan berapa total biaya pemesanan optimal untuk melakukan pengadaan bahan baku tepung. Alat analisis yang digunakan dalam penelitian ini adalah EOQ (Economic Order Quantity) yang meliputi perhitungan Quantity untuk mengetahui jumlah pemesanan bahan baku yang optimal, alat analisis ROP (Reorder Point) untuk mengetahui kapan waktu yang tepat untuk melakukan pemesanan bahan baku kembali, alat analisis Safety Stock untuk mengetahui persediaan pengaman dan TIC (Total Inventory Cost) untuk menghitung total biaya pemesanan bahan baku. Berdasarkan hasil analisis dengan metode EOQ, jumlah pesanan bahan baku yang optimal yaitu sebesar $3.179 \mathrm{Kg}$ dengan frekuensi pembelian 18 kali dalam satu tahun dengan pemesanan ulang bahan baku jika persediaan mencapai $704 \mathrm{Kg}$ dengan total biaya persediaan sebesar Rp. 351.827.600.
\end{abstract}

Kata kunci: Persediaan, Bahan Baku, Economic Order Quantity (EOQ).

1. Pendahuluan gandum yang paling utama adalah tepung terigu.

Salah satu makanan yang banyak digemari Tepung terigu adalah komoditas pangan yang bersifat masyarakat Indonesia salah satunya merupakan mudah diolah, memiliki harga terjangkau dan stabil. makanan pokok yang mengandung karbohidrat. Bahan Peningkatan konsumsi tepung terigu sejalan dengan makanan pokok tersebut seperti beras, gandum, sayur- konsumsi olahan pasta, biskuit dan roti. Meningkatnya sayuran, umbi-umbian dan buah-buahan. Olahan beras kebutuhan masyarakat akan produk olahan makanan yang dijadikan asupan makanan paling penting bagi dapat menciptakan peluang bagi pelaku usaha masyarakat indonesia yaitu nasi. Selain nasi yang pengolahan makanan, khususnya dalam pengolahan dijadikan asupan makanan paling penting yaitu olahan roti.

makanan yang terbuat dari gandum. Ditandai dengan Roti adalah produk makanan berbahan dasar meningkatnya impor gandum dari tahun ke tahun di tepung terigu yang proses pengolahanya mengalami Indonesia dengan satuan (ribuan ton), pada tahun 2016 fermentasi menggunakan ragi atau bahan pengembang sebesar 10.554 dan pada tahun 2017 sebesar 11.442 lain untuk memperoleh tekstur yang lembut dan empuk. (Kementerian Pertanian, 2018:07). Salah satu olahan Saat ini roti telah menjadi salah satu makanan yang

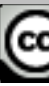

C 2021. Ayu Dewi Larasati, Naning Retnowati, Alwan Abdurahman, Financya Mayasari

Creative Commons Attribution 4.0 International License 
banyak dikonsusmsi oleh masyarakat di Indonesia. Berdasarkan fenomena yang terjadi pada usaha Secara umum roti biasanya dibedakan menjadi dua, Layla Bakery Jember maka penulis tertarik untuk yaitu roti tawar dan roti isi. Dengan fenomena tersebut melakukan penelitian mengenai peramalan dan menimbulkan banyak berdirinya usaha-usaha produksi pengendalian persediaan mendatang. Khususnya pada roti untuk dapat memenuhi kebutuhan pangan salah satu produk roti dengan menggunakan metode masyarakat. analisis Economic Order Quantity (EOQ). Tujuan

Layla Bakery Jember adalah salah satu usaha roti dilakukan penelitian ini antara lain : 1) Untuk yang berdiri sejak tahun 2015 dan berlokasi di Jalan mengetahui bagaimana cara menentukan perencanaan Ambulu No.110, Kecamatan Balung, Kabupaten pengendalian persediaan bahan baku tepung terigu Jember. Produk dari Layla Bakery Jember antara lain yang optimal dengan metode EOQ pada usaha Layla roti pisang, donat, roti, sisir dan lain-lain. Usaha Layla Bakery Jember; 2) Untuk mengetahui waktu yang tepat Bakery Jember memiliki 8 orang pegawai. Proses melakukan pemesanan bahan baku tepung terigu pada produksi yang dilakukan oleh Layla Bakery Jember usaha Layla Bakery Jember; 3) Untuk mengetahui total sekitar 1 sak $18 \mathrm{~kg}$ per hari secara terus menerus biaya yang harus dikeluarkan untuk persediaan bahan sehingga perusahaan tersebut mempunyai persediaan baku tepung terigu pada usaha Layla Bakery Jember. bahan baku.

Persediaan bahan baku adalah komponen yang 2. Metode Penelitian paling penting dalam proses produksi di suatu 2.1 Rancangan Penelitian perusahaan dan memiliki pengaruh yang signifikan Berdasarkan latar belakang masalah dan rumusan terhadap kelancaran proses produksi. Jika persediaan masalah yang ada penelitian ini merupakan penelitian bahan baku dilakukan dengan tepat dan optimal maka deskriptif dengan melakukan pendekatan kuantitatif. akan dapat menekan biaya secara efektif dan efisien Menurut Kuncoro (2013:12) penelitian deskriptif serta dapat meminimalisir tingginya biaya yang merupakan pengumpulan data untuk menguji hipotesis dikeluarkan perusahaan, seperti biaya penyimpanan dan atau menjawab setiap pertanyaan mengenai masalah biaya pemesanan. Dengan demikian pengendalian yang terdapat dalam perusahaan. Menurut Sugiyono persediaan yang terdapat pada perusahaan akan terjaga (2018:15) Pendekatan Kuantitatif merupakan dan mampu memenuhi kebutuhan konsumen dalam pendekatan berisi tentang angka-angka yang akan berbagai kondisi. Pada uasaha Layla Bakery Jember diolah dan dianalisis menggunakan analisis statistik. terdapat masalah yaitu volume penyimpanan pada Pada penelitian ini terdapat data yang akan diolah Layla Bakery Jember mengalami over stock atau berupa data harga bahan baku, persiapan persediaan kelebihan bahan baku pada setiap bulannya. Bahan bahan baku, data biaya penyimpanan, biaya baku yang dikirimkan cenderung berlebih sehingga pemesanan dan biaya pembelian.

usaha ini mengakibatkan terjadinya peningkatan pada

biaya penyimpanan, pemeliharaan tempat 2.2 Populasi Penelitian dan Teknik Pengambil Sampel penyimpanan, kerusakan bahan baku dan biaya 2.2.1 Populasi

pemesanan yang menyebabkan kecilnya keuntungan Populasi merupakan sebuah elemen wilayah yang diperoleh usaha Layla Bakery Jember,sehingga generalisasi yang berupa keseluruhan obyek yang dapat perlu melakukan pengendalian persediaan bahan baku. diukur dan diteliti (Sugiyono, 2018:130). Populasi

Salah satu metode yang tepat dalam merencanakan penelitian ini adalah perusahaan Layla Bakery Jember pengendalian persediaan bahan baku yaitu dengan bagian produksi dan data persediaan bahan baku pada menggunakan metode Economic Order Quantity usaha Layla Bakery Jember.

(EOQ). Menurut Heizer dan Render (2015:561), EOQ

merupakan teknik penyediaan persediaan yang 2.2.2 Teknik Pengambilan Sampel

meminimalkan total biaya pemesanan dan Metode pengumpulan data pada penelitian ini penyimpanan. Selain menggunakan EOQ, perusahaan dilakukan dengan metode Purposive Sampling yang juga perlu menentukan waktu perencanaan kembali teknik penentuan sampel dengan pertimbangan tertentu bahan baku yang akan digunakan atau Reorder Point (Sugiyono, 2018:138). Sampel yang dipilih adalah (ROP) adalah suatu titik atau batas dari jumlah sampel sumber data yaitu data pembelian bahan baku persediaan yang ada pada suatu dimana pemesanan pada bulan Januari - Desember tahun 2020, harus diadakan kembali. Safety Stock yang penggunaan bahan baku pada bulan Januari merupakan suatu kemampuan perusahaan untuk Desember tahun 2020, biaya pemesanan pada bulan menciptakan kondisi persediaan agar selalu aman dan Januari - Desember tahun 2020, meliputi biaya penuh dengan pengamanan dengan harapan perusahaan telepon dan biaya pembongkaran penerimaan bahan tidak akan mengalami kekurangan bahan baku pada baku, dan biaya penyimpanan pada bulan Januari saat melakukan proses produksi.

Desember tahun 2020. 


\subsection{Variabel Penelitian}

2.3.1 Klasifikasi Variabel dari orang, obyek atau kegiatan yang memiliki variasi alam yang banyak tersedia untuk diamati (Sugiyono, tertentu dan ditetapkan oleh peneliti untuk dapat 2018:166). Alat ukur yang digunakan dalam penelitian dipelajari serta ditarik kesimpulannya (Sugiyono, ini adalah dengan kuesioner terbuka untuk 2018:55). Adapun klasifikasi dalam penelitian mendapatkan data atau informasi mengenai pengendalian persediaan bahan baku pada Layla pengendalian persediaan bahan baku pada Layla Bakery Jember sebagai berikut:

a) Persediaan bahan baku

b) Penentuan jumlah pesanan ekonomis (Economic 2.5 Lokasi dan Waktu Penelitian Order Quantity)

c) Biaya Persediaan

d) Biaya total persediaan (TIC)

e) Pemesanan titik kembali (ROP)

\subsubsection{Definisi Operasional Variabel}

Berdasarkan variabel penelitian yang telah ditentukan, berikut definisi operasional variabel ada beberapa yang dapat dilakukakan utnuk mengenai masing-masing variabel yang telah pengumpulan data yaitu dengan setting, berbagai ditentukan.

a) Persediaan bahan baku adalah bahan baku tepung pengumpulan data sebagai berikut:

yang tersimpan di perusahaan untuk mendukung proses a. Sumber Primer (wawancara) merupakan sumber produksi dan menghindari fluktuasi harga bahan baku. data yang didapat secara langsung dengan melakukan Indikator yang digunakan dalam menentukan wawancara dengan pemilik usaha untuk mengetahui kebutuhan bahan baku adalah Kilogram (Kg).

informasi permasalahan pengendalian persediaan bahan b) Jumlah pesanan ekonomis adalah total setiap kali baku pada perusahaan dan data persediaan bahan baku pemesanan bahan baku tepung meminimalkan biaya pada perusahaan.

pengeluaran perusahaan.

b. Sumber Sekunder (dokumentasi) merupakan sumber c) Biaya persediaan bahan baku adalah biaya yang data yang didapat secara tidak langsung dengan dikeluarkan oleh perusahaan untuk membeli atau pengambilan dokumentasi gambar atau tulisan untuk menyimpan bahan baku tepung untuk kelancaran memperoleh data yang menyangkut persediaan bahan proses produksi. Biaya persediaan terdiri dari :

baku seperti data pembelian bahan baku dan

1. Biaya Pemesanan Total (Ordering Cost) adalah penggunaan bahan baku pada tahun tertentu.

biaya yang dikeluarkan oleh perusahaan untuk

pemesanan bahan baku tepung. Indikator yang 2.7 Teknik Analisis

digunakan untuk mengukur biaya pemesanan adalah 2.7.1 Analisis Kebutuhan Bahan Baku

Rupiah (Rp).

Pengolahan bahan baku menjadi faktor yang

2. Biaya Penyimpanan Total (Carrying Cost) adalah sangat penting bagi perusahaan dalam rangka menjaga biaya yang dikeluarkan perusahaan untuk kelancaran proses produksi. Sehingga bahan baku melakukan proses penyimpanan bahan baku tepung. merupakan kebutuhan utama yang harus selalu ada Indikator yang digunakan untuk biaya penyimpanan dalam proses produksi karena bahan baku akan diolah adalah Rupiah (Rp). menjadi produk jadi. Bahan baku yang dimaksudkan

d) Biaya Total Persediaan (Total Inventory Cost) dalam perusahaan yaitu berupa bahan baku tepung. adalah hasil penjumlahan biaya pemesanan dan Tepung merupakan komoditas pangan yang bersifat pembelian bahan baku tepung. Indikator yang mudah diolah, memiliki harga yang terjangkau dan digunakan dalam biaya total persediaan adalah Rupiah stabil.

(Rp).

Untuk menjaga kelancaran proses produksi, hal e) Pemesanan Ulang/Titik Kembali (Reorder Point) yang perlu diperhatikan oleh perusahaan yaitu adalah waktu yang tepat untuk melakukan pengadaan pembelian dan penggunaan bahan baku. Untuk dapat pemesanan bahan baku tepung kembali untuk menganalisis kebutuhan bahan baku yang akan kelancaran proses produksi. Indikator yang digunakan digunakan dalam memproduksi roti pada tahun dalam pemesanan ulang adalah Kilogram $(\mathrm{Kg})$. selanjutnya yaitu dengan menggunakan metode analisis moving average (pergerakan rata-rata). Adapun rumus yang digunakan dalam moving average menurut Handoko (2019:275), adalah sebagai berikut: 


$$
M A=\frac{\sum \mathrm{x}}{\text { Jumlah Periode }}
$$

Dengan keterangan bahwa perhitungan rata-rata dilakukan dengan bergerak kedepan untuk memperkirakan kebutuhan bahan baku di waktu yang akan datang dan dicatat dalam posisi terpusat pada rataratanya, dimana perhitungan rata-rata bergerak dapat $Z$ dilakukan dengan total gerakan tiga kuartal sehingga untuk nilai rata-rata bergerak terakhir dapat digunakan sebagai nilai ramalan periode berikutnya.

\subsubsection{Metode EOQ (Economic Order Quantity)}

Menurut Heizer dan Render (2015:563), metode

merupakan persediaan yang perlu dicadangkan untuk kebutuhan selama menunggu barang datang. Adapun rumus persediaan pengaman menurut Herjanto (2017: 259) dapat dihitung sebagai berikut:

\section{$S S=\mathrm{Z} \times \sigma$}

$$
\begin{aligned}
\mathrm{SS} & =\text { Safety Stock atau Persediaan pengaman } \\
\mathrm{Z} & =\text { Tingkat Pelayanan (Service Level) } \\
\sigma & =\text { Standar Deviasi }
\end{aligned}
$$

\subsubsection{Reorder Point (Ttitik Pemesan Kembali)}

Menurut Heizer dan Render (2015:567), Reorder point adalah titik (tingkat persediaan) dimana tindakan digunakan bahan baku. Berikut ini merupakan perhitungan mengendalikan persediaan bahan baku dengan reorder point menurut Haming dan Nurnajamuddin meminimalkan biaya total penyimpanan dan (2012:17) : pemesanan. Berikut rumus persamaan metode EOQ yaitu sebagai berikut :

$$
\mathrm{Q}^{*}=\sqrt{\frac{2 \mathrm{DS}}{\mathrm{H}}}
$$

Keterangan :

$\mathrm{Q}^{*}=$ Economic Order Quantity (EOQ)

$\mathrm{D}=$ Permintaan Selama Satu Tahun $(\mathrm{Kg})$

$\mathrm{S} \quad=$ Biaya Pemesanan Untuk Setiap Kali Pesan $(\mathrm{Rp})$

$\mathrm{H}$ = Biaya Penyimpanan Per Unit (Rp)

\subsubsection{Frekuensi Pembelian}

Metode EOQ mengacu pada pembelian dengan persediaan bahan baku. Berikut ini merupakan jumlah yang sama dalam setiap kali melakukan perhitungan besarnya Biaya Total Persediaan (Total pemesanan. Maka dari itu,jumlah pembelian dapat Inventory Cost) (Haming dan Nurnajamuddin, 2012:9) diketahui dengan cara membagi kebutuhan dalam satu : tahun dengan jumlah pembelian setiap kali pemesanan. Untuk lebih jelasnya dapat dilihat pada rumus yang diutarakan oleh Heizer dan Render (2015: 563) sebagai berikut :

$$
\mathrm{I}=\frac{\mathrm{D}}{\mathrm{EOQ}}
$$

$\mathrm{I}=$ Frekuensi Pembelian

$\mathrm{D}=$ Permintaan Selama Satu Tahun $(\mathrm{Kg})$

EOQ $=$ Jumlah Pemesanan Bahan Baku Optimal

\subsubsection{Persediaan Pengaman (Safety Stock)}

Menurut Herjanto (2017:258), safety stock adalah suatu persediaan yang dicadangkan sebagai kebutuhan selama menunggu waktu yang akan datang dan berfungsi untuk melindungi atau menjaga kemungkinan terjadinya kekurangan, baik itu barang yang lebih besar dari perkiraan semula atau keterlambatan dalam penerimaan barang yang dipesan. Sedangkan menurut Haming dan Nurnajamuddin (2012:17), safety stock merupakan unit persediaan yang harus selalu ada dalam perusahaan untuk mengatasi terjadinya fluktuasi permintaan. Sedangkan menurut Herjanto (2017:258-259), safety stock
Keterangan :

$\mathrm{SS}=$ Safety Stock atau persediaan pengaman

$\mathrm{d}=$ Rata-rata pemakaian selama satuan waktu

$\mathrm{L}=$ Lead Time atau waktu tunggu

2.7.6 Total Inventory Cost (Total Biaya Persediaan Bahan Baku)

Total Inventory Cost merupakan perhitungan biaya total persediaan yang digunakan untuk mengetahui total biaya yang dikeluarkan untuk persediaan bahan baku. Berikut ini merupakan

$$
\begin{gathered}
\mathrm{TIC}=\frac{D}{Q}(S)+\frac{Q}{2}(H) \text { atau } \mathrm{TIC}=\sqrt{2 D S H} \\
\mathrm{TC}=\mathrm{TIC}+\mathrm{DC}
\end{gathered}
$$

Keterangan :

TIC = Biaya variabel persediaan $(\mathrm{Rp})$

$\mathrm{D}=$ Kebutuhan bahan baku per tahun $(\mathrm{Kg})$

$\mathrm{Q}=$ Unit yang dipesan per order $(\mathrm{Kg})$

$\mathrm{S}=$ Biaya pesanan per order $(\mathrm{Rp})$

$\mathrm{H}=$ Biaya unit penyimpanan per tahun $(\mathrm{Rp})$

$\mathrm{TC}=$ Biaya total persediaan/Total inventory cost $\mathrm{Rp})$

\section{Hasil dan Pembahasan}

3.1.1 Analisis Kebutuhan Bahan Baku

a. Pembelian Bahan Baku

Layla Bakery Jember melakukan pembelian bahan baku pada Toko Trio di Jenggawah Jember. Pembelian bahan baku tepung pada Layla Bakery Jember dilakukan selama 7 hari sekali dengan pemesanan bahan baku sebanyak $4.000 \mathrm{Kg}$, sehingga dalam satu bulan Layla Bakery Jember mampu mendatangkan bahan baku sebanyak 4 kali dengan perolehan bahan baku $16.000 \mathrm{Kg}$. Berikut data pembelian bahan baku pada bulan Januari - Desember 2020. 
Tabel 1. Pembelian Bahan Baku Dalam Satuan Kilogram (Kg).

\begin{tabular}{|c|l|c|}
\hline No & \multicolumn{1}{|c|}{ Bulan } & Pembelian (Kg) \\
\hline 1 & Januari & 16.000 \\
\hline 2 & Februari & 16.000 \\
\hline 3 & Maret & 12.000 \\
\hline 4 & April & 12.000 \\
\hline 5 & Mei & 16.000 \\
\hline 6 & Juni & 16.000 \\
\hline 7 & Juli & 16.000 \\
\hline 8 & Agustus & 16.000 \\
\hline 9 & September & 16.000 \\
\hline 10 & Oktober & 16.000 \\
\hline 11 & November & 16.000 \\
\hline 12 & Desember & 16.000 \\
\hline & Jumlah & $\mathbf{1 8 4 . 0 0 0}$ \\
\hline & Rata - rata & $\mathbf{1 5 . 3 3 3}$ \\
\hline
\end{tabular}

Perhitungan untuk pembelian bahan baku tepung terigu pada Layla Bakery Jember yaitu :

a. Pemesanan bahan baku $\mathrm{x}$ banyaknya mendatangkan bahan baku selama 1 bulan

$=4.000 \mathrm{Kg} \mathrm{x} 4$ kali

$=16.000 \mathrm{Kg}$

b. Rata-rata pembelian bahan baku

= Jumlah pembelian / 12 bulan

$=184.000 \mathrm{Kg} / 12$

$=15.333 \mathrm{Kg}$.

Berdasarkan tabel 1. pembelian bahan baku tepung pada bulan Januari -Desember 2020 mengalami penurunan pada bulan Maret dan April tahun 2020 dikarenakan adanya lockdown penyebaran virus corona sehingga permintaan roti mengalami penurunan.

\section{Namun pada setiap bulannya kecuali pada bulan Maret 3.1.2 Perhitungan Metode EOQ (Economic Order} dan April memiliki nilai yang konstan sebanyak 16.000 Quantity)

Kg. Pembelian bahan baku tepung pada Layla Bakery Jember dilakukan setiap 7 hari sekali sehingga pabrik mampu mendatangkan bahan baku $4000 \mathrm{Kg}$ dan diperoleh setiap bulannya $16.000 \mathrm{Kg}$ dengan frekuensi pembelian tahunan dua belas kali per tahun, sehingga rata-rata pembelian bahan baku $15.333 \mathrm{Kg}$.

\section{b. Penggunaan Bahan Baku} Layla Bakery Jember melakukan proses produksi pembongkaran bahan baku tepung. Untuk lebih setiap hari maksimal 9 sak bahan baku tepung dengan jelasnya dapat dilihat pada tabel 3 .

kapasitas sekitar 1 sak $18 \mathrm{Kg}$. Sehingga maksimal kapasitas produksi yang dilakukan oleh Layla Bakery dalam setiap harinya sebesar $162 \mathrm{Kg}$. Adapun penggunaan bahan baku tepung pada bulan Januari Desember 2020 dapat dilihat dari tabel 2.

Tabel 2. Penggunaan Bahan Baku Tepung Pada Tahun 2020

\begin{tabular}{|c|l|c|c|}
\hline No & Bulan & Hari Kerja & $\begin{array}{c}\text { Penggunaan Bahan Baku } \\
(\mathbf{K g})\end{array}$ \\
\hline 1 & Januari & 31 & 5.022 \\
\hline 2 & Februari & 29 & 4.698 \\
\hline 3 & Maret & 28 & 4.536 \\
\hline 4 & April & 27 & 4.374 \\
\hline 5 & Mei & 31 & 5.022 \\
\hline 6 & Juni & 30 & 4.860 \\
\hline 7 & Juli & 31 & 5.022 \\
\hline 8 & Agustus & 31 & 5.022 \\
\hline 9 & September & 30 & 4.860 \\
\hline 10 & Oktober & 31 & 5.022 \\
\hline 11 & November & 30 & 4.860 \\
\hline 12 & Desember & 31 & 5.022 \\
\hline Jumlah & 360 & $\mathbf{5 8 . 3 2 0}$ \\
\hline \multicolumn{2}{|l|}{ Rata-rata } & & 4.860 \\
\hline
\end{tabular}

Perhitungan untuk penggunaan bahan baku pada Layla Bakery Jember yaitu :

a. Penggunaan bahan baku $=$ Kapasitas produksi $\mathrm{x}$ Hari kerja

b. Rata-rata Penggunaan bahan baku = Jumlah penggunaan bahan baku / 12 bulan

$=58.320 \mathrm{Kg} / 12$

$=4.860 \mathrm{Kg}$.

Penggunaaan bahan baku dipengaruhi oleh pembelian bahan baku, hari kerja produksi dan kapasitas produksi dalam perusahaan. Kapasitas produksi tiap harinya yaitu $162 \mathrm{Kg}$ dan penggunaaan bahan baku pada Januari - Desember 2020 dengan total $58.320 \mathrm{Kg}$ dengan rata-rata $4.860 \mathrm{Kg}$ dengan jumlah hari kerja dalam satu tahun yaitu 360 hari.

\section{a. Biaya Pemesanan}

Adanya pembelian atau pemesanan bahan baku menimbulkan suatu biaya yaitu biaya pemesanan (Ordering Cost). Biaya pemesanan yang timbul akibat perusahaan melakukan pemesanan atau pembelian bahan baku yaitu biaya

telepon, biaya pengiriman, biaya angkut dan biaya

Tabel 3. Biaya Pemesanan Tahun 2020

\begin{tabular}{|c|c|c|}
\hline No & \multicolumn{1}{|c|}{ Jenis biaya } & Jumlah biaya (Rp) \\
\hline 1 & Biaya telepon & 2.000 \\
\hline 2 & Biaya pengiriman dan pembongkaran & 50.000 \\
\hline & Total & $\mathbf{5 2 . 0 0 0}$ \\
\hline
\end{tabular}


Berdasarkan pada tabel 3. dapat dilihat biaya c. Metode Economic Order Quantity (EOQ)

pemesanan dalam setiap kali pemesanan bahan baku Perhitungan metode Economic Order Quantity tepung yaitu Rp. 2.000 untuk biaya telepon, dimana (EOQ) bertujuan untuk mengetahui jumlah pemesanan biaya telepon diperoleh dari asumsi penggunaan bahan baku yang optimal untuk kelancaran proses telepon selama 10 menit dengan menggunakan produksi. Metode Economic Order Quantity provider telkomsel dan asumi biaya per menit sebesar menggunakan biaya pemesanan, biaya penyimpanan Rp. 200, sedangkan untuk biaya pengiriman dan dan jumlah penggunaan bahan baku. Berikut pembongkaran sebesar Rp. 50.000 yang ditetapkan penggunaan EOQ dapat dilihat pada tabel 6 .

oleh pemasok kepada perusahaan pada saat proses

pemuatan bahan baku dilakukan. Untuk lebih jelasnya Tabel 6. Penggunaan Bahan Baku Tepung, Harga dapat dilihat pada perhitungan berikut:

Biaya telepon $=$ Rp. $200 \times 10$ menit

$=$ Rp. $2.000 /$ pesanan

Biaya angkut dan pembongkaran ditetapkan oleh pemasok $=$ Rp. 50.000/ pesanan Sehingga untuk biaya pemesanan perusahaan tahun 2020 yaitu :

Tabel 4. Biaya Pemesanan Perusahaan Selama Tahun 2020

\begin{tabular}{ccrrr}
\hline No & Jenis biaya & $\begin{array}{c}\text { Biaya pesanan } \\
\text { (Biaya telepon) } \\
\text { (Rp) (a) }\end{array}$ & $\begin{array}{c}\text { Frekuensi } \\
\text { pemesanan } \\
\text { (kali) (b) }\end{array}$ & $\begin{array}{c}\text { Total biaya } \\
\text { pemesanan } \\
\text { tahun 2019 } \\
\text { (Rp) (axb) }\end{array}$ \\
\hline $1 \quad$ & 2.000 & 48 & 96.000 \\
& $\begin{array}{l}\text { Biaya telepon } \\
\text { Biaya pengiriman } \\
\text { dan pembongkaran }\end{array}$ & 50.000 & 48 & 2.400 .000 \\
\hline \multicolumn{7}{c}{ Jumlah } & $\mathbf{5 2 . 0 0 0}$ & & $\mathbf{2 . 4 9 6 . 0 0 0}$ \\
\hline
\end{tabular}

Bahan Baku Dan Biaya Persediaan Bahan Baku Tahun 2020 .

\begin{tabular}{|c|c|c|c|c|}
\hline \multicolumn{3}{|c|}{ Penggunaan bahan baku } & \multirow[b]{2}{*}{$\begin{array}{c}\text { Jumlah } \\
\text { Biaya } \\
\text { pemesanan } \\
\text { (Rp) }\end{array}$} & \multirow[b]{2}{*}{$\begin{array}{c}\text { Total Biaya } \\
\text { penyimpanan } \\
\text { (Rp) }\end{array}$} \\
\hline $\begin{array}{c}\text { Jumlah } \\
\text { Penggunaan } \\
\text { Bahan Baku } \\
\text { (a) (kg) }\end{array}$ & $\begin{array}{c}\text { Rata - rata } \\
\text { Harga } \\
\text { Persediaan per } \\
\text { Kg (Rp) (b) }\end{array}$ & $\begin{array}{l}\text { Total biaya } \\
\text { (Rp) (axb) }\end{array}$ & & \\
\hline 58.320 & 6.000 & 349.920 .000 & 52.000 & 6.00 \\
\hline
\end{tabular}

Berdasarkan tabel diatas, maka metode EOQ dapat dihitung dengan menggunakan rumus sebagai berikut :

$$
\begin{aligned}
& \mathrm{Q}^{*}=\sqrt{\frac{2 \mathrm{DS}}{\mathrm{H}}} \\
& \mathrm{Q}^{*}=\sqrt{\frac{2 \times 58.320 \times 52.000}{600}}
\end{aligned}
$$

b. Biaya Penyimpanan

Biaya penyimpanan dihitung dalam bentuk persentase, yaitu persentase dari harga persediaan (harga dari bahan baku). Persentase yang ditetapkan oleh perusahaan yaitu sebesar $10 \%$. Hal ini dikarenakan perusahaan melakukan proses produksi setiap hari sehingga waktu penyimpanan bahan baku digudang tidak terlalu lama. Untuk lebih jelasnya biaya penyimpanan dapat dilihat pada tabel 5 berikut ini.

Tabel 5. Biaya Penyimpanan Bahan Baku Tepung

\begin{tabular}{ccc}
\hline $\begin{array}{c}\text { Rata - rata harga } \\
\text { persediaan per } \mathrm{Kg}(\mathrm{Rp})(\mathrm{a})\end{array}$ & $\begin{array}{c}\text { \% Biaya } \\
\text { persediaan (b) }\end{array}$ & $\begin{array}{c}\text { Biaya penyimpanan } \\
\text { (Rp) (axb) }\end{array}$ \\
\hline 6.000 & $10 \%$ & 600
\end{tabular}

Berdasarkan tabel 5, dapat dilihat bahwa rata-rata harga persediaan bahan baku pada tahun 2020 yaitu Pada tahun 2020 Layla Bakery Jember melakukan sebesar Rp 6.000, Untuk persentase biaya persediaan pembelian bahan baku setiap kali pesan yaitu sebesar yaitu $10 \%$ dari rata- rata harga persediaan bahan baku. $3.179 \mathrm{Kg}$ dengan frekuensi pembelian setiap tahun Akumulasi persentase tersebut dinyatakan oleh Haming yaitu sebesar 18 kali pemesanan. Pada tahun 2020 dan Nurnajamuddin (2012:8), bahwa biaya jumlah pembelian bahan baku tepung satu kali pesan penyimpanan umumnya dihitung dengan persen yang harus dipesan oleh Layla Bakery Jember yaitu tertentu terhadap harga persediaan per kg. Sehingga $3.179 \mathrm{Kg}$. Sehingga untuk satu tahun dapat melakukan persentase biaya penyimpanan yang ditentukan oleh pembelian bahan baku tepung sebanyak 18 kali perusahaan yaitu sebesar $10 \%$ dari rata-rata harga dengan jangka waktu 20 hari sekali.

bahan baku per Kg selama tahun 2020.

Organizer : Jurusan Manajemen Agribisnis 
3.1.3 Perhitungan Safety Stock (Persediaan Pengaman)

Persediaan pengamanan atau safety stock atau total cost bertujuan untuk mengetahui berapa merupakan persediaan bahan baku yang harus terdapat jumlah biaya persediaan total yang dikeluarkan oleh di perusahaan untuk menghindari kekurangan bahan Layla Bakery Jember tahun 2020. Biaya total baku sehingga dapat menghambat proses produksi persediaan bahan baku ini terdiri dari biaya variabel dalam perusahaan. Derajat deviasi yang digunakan dan biaya tetap. Berikut ini merupakan rumus yang yaitu sebesar 95\% dengan nilai 1,645 dimana dapat digunakan untuk menghitung baya total perusahaan mampu untuk memenuhi kebutuhan.

Standar deviasi pada tahun 2020 yaitu $209 \mathrm{Kg}$, dan diketahui bahwa service level yang digunakan yaitu $95 \%$ dengan nilai 1,645. Sehingga untuk mengetahui besarnya persediaan pengaman (Safety stock) dapat Keterangan: dihitung menggunakan rumus berikut :

$$
\text { SS }=\mathrm{Z} \times \sigma
$$

Keterangan :

$\mathrm{SS}=$ Safety Stock

$\mathrm{Z}=$ Tingkat layanan sediaan

$\sigma=$ Standar deviasi

Maka,

$\mathrm{SS}=\mathrm{Z} \times \sigma$

$\mathrm{SS}=1,645 \times 209$

$\mathrm{SS}=344 \mathrm{Kg}$

Jadi safety stock atau sediaan pengaman yang harus ada dalam Layla Bakery Jember tahun 2020 yaitu 344 $\mathrm{Kg}$.

\subsubsection{Reorder Point (Ttitik Pemesanan Kembali)}

Penentuan reorder point atau titik pemesanan kembali bertujuan untuk mengetahui pada tingkat jumlah bahan baku tertentu, perusahaan harus melakukan pemesanan kembali bahan baku, sehingga ketika bahan baku yang terdapat pada gudang habis digunakan, maka bahan baku yang dipesan telah diterima oleh perusahaan.

Perhitungan reorder point dapat dihitung berdasarkan rumus berikut ini:

$$
R O P=S S+d L
$$

Keterangan :

SS $=$ Safety Stock atau persediaan pengaman

$\mathrm{d}=$ Rata-rata pemakaian selama satuan waktu

$\mathrm{L}=$ Lead Time atau waktu tunggu

Maka,

$$
\begin{aligned}
& R O P=\mathrm{SS}+d L \\
& R O P=344+360 \times 1 \\
& \mathrm{ROP}=704 \mathrm{Kg} .
\end{aligned}
$$

Pada tahun 2020 Layla Bakery Jember melakukan pemesanan ulang pada persediaan bahan baku sebesar $704 \mathrm{Kg}$.

3.1.5 Total Inventory Cost (Total Biaya Persediaan Bahan Baku) persediaan bahan baku pada tahun 2020:

$$
\begin{aligned}
& \mathrm{TC}=\mathrm{TIC}+\mathrm{DC} \\
& \mathrm{TIC}=\sqrt{2 D S H}
\end{aligned}
$$

TIC = Biaya variabel persediaan $(\mathrm{Rp})$

$\mathrm{D}=$ Kebutuhan bahan baku per tahun $(\mathrm{Kg})$

$\mathrm{S} \quad=$ Biaya pemesanan per order $(\mathrm{Rp})$

$\mathrm{H}=$ Biaya unit penyimpanan per tahun $(\mathrm{Rp})$

$\mathrm{TC}=$ Biaya total persediaan/Total Inventory Cost $(\mathrm{Rp})$

$\mathrm{DC}=$ Harga sediaan yang diperlukan dalam satu tahun (Rp)

Untuk mencari biaya total persediaan, terlebih dahulu menghitung biaya variabel yang terdiri dari biaya pemesanan bahan baku dan biaya penyimpanan bahan baku sebagai berikut :

$$
\begin{aligned}
& \mathrm{TIC}=\sqrt{2 D S H} \\
& \mathrm{TIC}=\sqrt{2 \times 58.320 \times 52.000 \times 600} \\
& \mathrm{TIC}=\text { Rp. } 1.907 .660
\end{aligned}
$$

Jadi biaya variabel persediaan pada Layla Bakery Jember tahun 2020 yaitu sebesar Rp. 1.907.660. Sedangkan untuk menghitung total biaya persediaan yang terdapat pada Layla Bakery Jember yaitu dengan menjumlahkan biaya variabel dan biaya tetap, dimana yang merupakan biaya tetap yaitu harga dari persediaan itu sendiri.

Adapun perhitungan dari total biaya persediaan yaitu sebagai berikut:

$$
\begin{aligned}
\text { DC } & =\mathrm{D} \times \text { rata-rata harga bahan baku } \\
& =58.320 \times \text { Rp. } 6.000 \\
& =\text { Rp. } 349.920 .000 \\
\text { TC } & =\text { TIC }+ \text { DC } \\
\text { TC } & =\text { Rp. } 1.907 .660+\text { Rp. } 349.920 .000 \\
\text { TC } & =\text { Rp. } 351.827 .660
\end{aligned}
$$

Jadi total biaya persediaan /Total cost yang terdapat pada Layla Bakery Jember tahun 2020 berdasarkan metode EOQ yaitu sebesar Rp. 351.827.660.

\subsubsection{Pengendalian Persediaan Perusahaan}

Layla Bakery merupakan usaha agroindustri yang memproduksi komoditi tepung menjadi produk roti. Perusahaan tersebut memiliki kapasitas produksi tepung setiap harinya sebanyak 1 sak $18 \mathrm{Kg}$. Untuk 
kelancaran proses produksinya, Layla Bakery Perusahaan dapat melakukan pemesanan bahan baku melakukan pembelian bahan baku tepung sebanyak kembali pada saat bahan baku yang terdapat di gudang $4.000 \mathrm{Kg}$ setiap 7 hari sekali sehingga dalam satu bulan sebanyak $704 \mathrm{Kg}$. Sehingga berdasarkan metode EOQ Layla Bakery mampu mendatangkan bahan baku tersebut, perusahaan Layla Bakery dapat mengeluarkan tepung sebanyak 4 kali dengan perolehan bahan baku total biaya persediaan selama satu tahun sebesar Rp. 16.000 Kg. Dengan adanya proses produksi setiap hari 351.827.660. Untuk mengetahui lebih jelas penggunaan maka diperlukan persediaan yang disimpan di gudang metode EOQ pada perusahaan dapat dilihat pada tabel penyimpanan. Dalam pengendalian persediaan bahan 7 sebagai berikut:

baku tepung, perusahaan menggunakan bahan baku

yang pertama kali di gudang untuk melakukan proses Tabel 7. Perbandingan Persediaan Bahan Baku Tepung produksi. Hal tersebut dikarenakan untuk menjaga Yang Terdapat Di Perusahaan Dan Menggunakan kualitas bahan baku tepung, untuk menjaga kualitas Metode EOQ Pada Tahun 2020

bahan baku tepung maka bahan baku yang datang lebih awal terlebih dahulu digunakan untuk proses produksi sehingga bahan baku tersebut tidak disimpan di gudang terlalu lama yang nantinya akan mengakibatkan kerusakan terhadap bahan baku. Dengan adanya pembelian bahan baku tepung menimbulkan suatu biaya yang harus dikeluarkan oleh Layla Bakery Jember. Adapun perhitungan biaya persediaan berdasarkan siklus produksi yang dilakukan oleh perusahaan, yaitu sebagai berikut:

$\mathrm{TIC}=(\overline{\mathrm{x}} \times \mathrm{H})+(\mathrm{S} \times$ Frekuensi Pembelian $)$

$\mathrm{TIC}=($ Persediaan rata-rata $\mathrm{x}$ biaya simpan $)+($ Biaya pemesanan $\mathrm{x}$ frekuensi pembelian)

$\mathrm{TIC}=(4.860 \times 600)+(52.000 \times 48)$

$\mathrm{TIC}=2.916 .000+2.496 .000$

$=\operatorname{Rp} 4.692 .000$

\begin{tabular}{|l|c|c|}
\hline \multicolumn{1}{|c|}{ Keterangan } & $\begin{array}{c}\text { Perusahaan } \\
2020\end{array}$ & $\begin{array}{c}\text { Metode EOQ } \\
2020\end{array}$ \\
\hline $\begin{array}{l}\text { Kuantitas Pembelian } \\
\text { (Kg) }\end{array}$ & 16.000 & 3.179 \\
\hline $\begin{array}{l}\text { Frekuensi Pembelian } \\
\text { (Kali) }\end{array}$ & 48 & 18 \\
\hline $\begin{array}{l}\text { Persediaan Pengaman } \\
\text { (Safety Stock) }\end{array}$ & - & 344 \\
\hline $\begin{array}{l}\text { Titik Pemesanan } \\
\text { Kembali (Reorder Point) } \\
\text { Kg) }\end{array}$ & - & 704 \\
\hline $\begin{array}{l}\text { Total Biaya Persediaan } \\
\text { (TIC) (Rp) }\end{array}$ & 354.612 .000 & 351.827 .660 \\
\hline
\end{tabular}

Dari tabel diatas dapat dilihat bahwa perusahaan tidak menerapkan persediaan pengaman (Safety Stock) dan titik pemesanan kembali (Reorder Point). Akibat dari tidak menerapkan persediaan pengaman (safety stock) hal tersebut menyebabkan terjadinya resiko kekurangan bahan baku sehingga mengakibatkan keterhambatan dalam melakukan proses produksi. Sedangkan jika sebuah perusahaan tidak menerapkan titik pemesanan kembali (reorder point) akan mengakibatkan perusahaan tersebut terlalu sering melakukan pembelian bahan baku sehingga biaya yang dikeluarkan semakin besar dan berpengaruh untuk kelancaran proses produksi selanjutnya. Pada tabel 8 dapat diketahui penghematan yang diperoleh

Dari perhitungan diatas maka diperoleh biaya persediaan yang dikeluarkan oleh Layla Bakery Jember tahun 2020 yaitu sebesar Rp 354.612.000.

3.2.2 Pengendalian Persediaan Perusahaan Berdasarkan Metode EOQ

Berdasarkan data yang diperoleh dari perusahaan, maka dapat dihasilkan perhitungan Economic Order Quantity (EOQ), Safety Stock (SS), Reorder Point (ROP), dan Total Cost (TC). Berdasarkan metode EOQ, Layla Bakery Jember pada tahun 2020 dapat melakukan pembelian bahan baku tepung dengan jumlah pembelian bahan baku sebanyak $3.179 \mathrm{Kg}$ tiap kali pesan dan frekuensi pembelian sebanyak 18 kali dalam satu tahun dengan waktu pemesanan bahan baku setiap 20 hari sekali. Untuk mengatasi adanya kekurangan datangnya bahan baku, Layla Bakery harus memiliki persediaan pengaman sebanyak $344 \mathrm{Kg}$. perusahaan dari selisih antara perusahaan menerapkan metode EOQ dengan tidak menerapkan metode EOQ.

Tabel 8. Selisih Antara Perusahaan Menerapkan Metode EOQ Dengan Tidak Menerapkan Metode EOQ.

\begin{tabular}{c|c|c|c}
\hline Tahun & $\begin{array}{c}\text { TIC menurut } \\
\text { Perusahaan (Rp) }\end{array}$ & $\begin{array}{c}\text { TIC menurut } \\
\text { Metode EOQ (Rp) }\end{array}$ & $\begin{array}{c}\text { Penghematan } \\
\text { Biaya (Rp) }\end{array}$ \\
\hline 2020 & 354.612 .000 & 351.827 .660 & 2.784 .340 \\
\hline
\end{tabular}

Dari tabel diatas maka perusahaan akan memperoleh penghematan biaya pada tahun 2020 sebesar Rp. 2.784.340 dengan menerapkan metode EOQ.

\section{Kesimpulan dan Saran}

4.1 Kesimpulan

1) Layla Bakery Jember dapat melakukan pemesanan bahan baku dengan jumlah pemesanan yang optimal (EOQ) pada tahun 2020 yaitu 
sebanyak 3.179 Kg dalam satu kali pemesanan. mengendalikan ketika kekurangan atau kelebihan bahan Pemesanan bahan baku dapat dilakukan setiap 20 baku yang terdapat di Layla Bakery Jember. hari sekali, sehingga pada tahun 2020 dapat Daftar Rujukan

dilakukan pemesanan bahan baku sebanyak 18 [1] Fajrin, E.H. 2013. Analisis Pengendalian Persediaan Bahan kali.

2) Waktu yang tepat dalam melakukan pemesanan kembali (reorder point) bahan baku yang harus dilakukan oleh Layla Bakery Jember tahun 2020 yaitu pada saat bahan baku yang terdapat di gudang sebanyak $704 \mathrm{Kg}$.

3) Total biaya persediaan yang dikeluarkan perusahaan Layla Bakery Jember tahun 2020 dengan menggunakan metode EOQ yaitu sebesar Rp 351.827.660.

\subsection{Saran}

Sebaiknya perusahaan menerapkan metode Economic Order Quantity untuk mampumengendalikanpersediaan bahan baku tepung dan mengoptimalkan jumlah pesanan sehingga dapat mengurangi biaya persediaan yang dikeluarkan perusahaan. Pada Layla Bakery diharapkan dapat menerapkan Safety Stock (persediaan pengaman) dan Reorder Point (pemesanan ulang) untuk menghindari kerugian yang dikeluarkan perusahaan dan dapat Baku Dengan Menggunakan Metode Economic Order Quantity (ROQ) Pada Perusahaan Roti Bonansa. Skripsi. Universitas Negeri Semarang.

[2] Fahmi, I. 2016. Manajemen Produksi dan Operasi. Bandung: Penerbit Alfabeta.

[3] Haming, M. dan M., Nurnajamuddin. 2012. Manajemen Produksi Modern : Operasi Manufaktur dan Jasa. Jakarta : Bumi Aksara.

[4] Heizer, J. dan R., Barry. 2015. Manajemen Operasi: Manajemen Keberlangsungan dan Rantai Pasok Edisi 11. Jakarta: Salemba Empat.

[5] Indah, D. Rosa, Purwasih, L. dan Maulidia, Z. 2018. "Pengendalian Persediaan Bahan Baku Pada PT. Aceh Rubber Industries Kabupaten Aceh Tamiang" Dalam Jurnal Manajemen dan Keuangan, Vol 7 No 2. Hal. 157.

[6] Joko, S. 2001. Manajemen Produksi \& Operasi. Cetakan Pertama. Malang: Universitas Muhammadiyah Malang.

[7] Kuncoro, M. 2013. Metode Riset untuk Bisnis dan Ekonomi Edisi 4. Jakarta:Erlangga.

[8] Subagyo, P., M, Asri, dan H, Handoko. 1999. Dasar - Dasar Operation Research. Cetakan 12. Yogyakarta: BPFE.

[9] Sugiyono. 2018. Metode Penelitian Kuantitatif. Bandung : Alfabeta.

[10] Wahyuni, I. 2016. Analisis Pengendalian Persediaan Bahan Baku Tahu Dengan Metode Economic Order Quantity Pada UD Jaya Abadi Kabupaten Situbondo. Skripsi. Politeknik Negeri Jember. 